\title{
Impact of Smartphone Features on "Omset" Services Online Car Rental
}

\author{
Marhayanie \\ Accounting Departement \\ Economic \& Bussiness Faculty \\ Universitas Sumatera Utara \\ marhayanie@usu.ac.id
}

\author{
Mutia Ismail \\ Accounting Departement \\ Economic \& Bussiness Faculty \\ Universitas Sumatera Utara \\ mutiaismail@usu.ac.id
}

\author{
Iskandar Muda \\ Accounting Departement \\ Economic \& Bussiness Faculty \\ Universitas Sumatera Utara \\ iskandar1@usu.ac.id
}

\begin{abstract}
The purpose of this study is to know the level of community knowledge of the smartphone features with Learning and Asking its use to increase the turnover of car rental service sales in Medan. This research type is descriptive quantitative with student population of rental user in Medan City. The selected sample is 110 respondent. Analytical tool of this research is with Structural Equation Modeling with the help of Smart-PLS software. The results show the level of community knowledge of smartphone features obtained through Asking to ask more effectively to know the features of a smartphone than with a selflearning approach.
\end{abstract}

Keywords_Learning; Asking; Knowledge; and Features

\section{INTRODUCTION}

The combination of technological and transportation developments and encourage the development of online transportation business like Gojek. Although actually this company has been pioneered since 2010, but Gojek then grow rapidly in 2015 when utilizing Android and iOS applications to support the marketing of their transport services. In addition to Gojek, the transportation company that started to get a place in the hearts of Indonesian consumers is Grab [1]. Grab is a Singapore-based company that provides online transport applications in six countries: Malaysia, Singapore, Thailand, Vietnam, Indonesia and the Philippines[13]. Grab has a vision to revolutionize the industry of testimony, so as to provide security and comfort for vehicle users throughout Southeast Asia. Currently Grab has been operating in seven major cities in Indonesia, namely Jakarta, Bandung, Surabaya, Bali, Padang, Medan, and Makassar. Grab-based digital vehicle ordering application has performed very well in Indonesia [40].

The development of mobile computing technology has increased rapidly, this is marked by the increasing number of functions on the mobile device. This becomes an evolution of mobile devices in this case is a mobile phone that marked the birth of technology gadgets whose capabilities are almost similar to a personal computer[2], [3],[5],[6]\&[18]. The smartphone gadget is a new class of mobile phone technology that can facilitate access and processing of data with significant computing power. In this technological era, smartphone gadgets are an incredible tool. The smartphone gadget not only helps to stay in touch with freight carrier application providers. The smartphone gadget is a phone that offers more advanced computing capabilities and connectivity than contemporary phone features[7]\&[12]. Smartphone gadgets and phone features are sometimes regarded as handheld computers that are integrated with mobile phones[6], [19], [20]. Ease of Use is defined as a level where one believes that a feature can be easily understood. On the basis of such a definition of ease of use of application features means ease in understanding when transacting primarily online transport services. The perception of ease of use provides several indicators against an information system that includes the efficiency of time in use, the appearance of the site easy to understand, add skills in using it, and easy to learn[33], [35],[36]\&[47], The intensity of use and interaction between users with the system can also indicate ease of use. A frequently used system shows that the system is better known, and easier to use by its users. Ease of use will reduce the efforts of customers in learning the origins of transactions behavior through the Internet[37]\&[46]. Ease of use also provides an indication that the users of information systems can work more easily than those who work without using information systems. Thus, if the services of online transport perceived easy to use by the users, the service will also be perceived useful[28],[29]\&[31]. Perceptions of the ease of use of technology and perceptions of the use of a technology related to one's attitude on the use of technology[23]. Attitude on the use of something is like or dislike toward the use of a product. This attitude can be used to predict a person's intentional behavior to use a product or not to use it. The use of technology shows an individual's interest in using or not using technology in accomplishing a series of tasks. Ideally, in conjunction with tech-task matching factors, the use of technology is measured by how much the user wants to use the system, the suitability of the need, the support in using it, and recommending it to others[44],[45]\&[46]. Such operationalization reflects the user's interest in using the technology based on the results of his evaluation of technological compatibility factors so that the use of technology takes place in a voluntary situation[41],[42]\&[43]. However, such proportions are extremely difficult in field studies. As a solution, for utilization to be actualized as how broadly integrated information systems are to each individual task, either by individual choice or by organizational mandate. The interest in using technology reflects the behavior of individuals in accepting a system. This is by asking how much of a user's dependence on the various lists of Internet-based information systems available to the organization. 


\section{METHOD}

This study usesprimary data.The hypothesis was tested by using Structural Equation Modeling (SEM) with SMART PLS software. The data analysis technique in this research employed Structural Equation Modeling (SEM). SEM is a set of statistical techniques allowing testing of a series of relationshipssimultaneously[21],[22],[23],[24],[25],[26]\&[27].

Furthermore, in the data processing, the writer used the aid from software SMART-PLS Structural Equation Modeling, which was one of the multivariate analyses capable of analyzing the variable relationships in complex manner [15], [16] \& [17].The hypotheses were tested using Structural Equation Modeling (SEM) with Smart-PLS software tools. The equation is formed as follows:

$$
\begin{array}{ll}
\mathrm{Y}=\alpha+\mathrm{b} 1 \mathrm{X} 1 & +\mathrm{b} 2 \mathrm{X} 2+\mathrm{e} \\
\mathrm{X} 1 & =\text { Learning } \\
\mathrm{X} 2 & =\text { Asking } \\
\mathrm{Y} & =\text { Knowledge } \\
\mathrm{b} 1, \ldots \mathrm{b} 3 & =\text { Coefficient } \\
\alpha & =\text { Constant } \\
\mathrm{e} & =\text { Error }
\end{array}
$$

This phase is done to test the suitability of the model to evaluate the goodness-of-fit index. Analysis using SEM requires some suitability index to measure the correctness of data and models.

\section{RESULT}

\section{A. Result}

Inner model evaluation through the bootstrapping menu also generates T-statistics values that will be used to test the hypothesis. The indicator can be used to confirm that the indicator can together with other indicators explain a latent variable. In other words factor loading analysis is used to see the ability of the proposed indicator in building latent variables.The criteria are T-statistic> 1.66 [8], [9], [10]\&[11]. The result of T-statistics value in the table path coefficients is presented in the following figure:

Figure 1. Overall Model with Coefficient

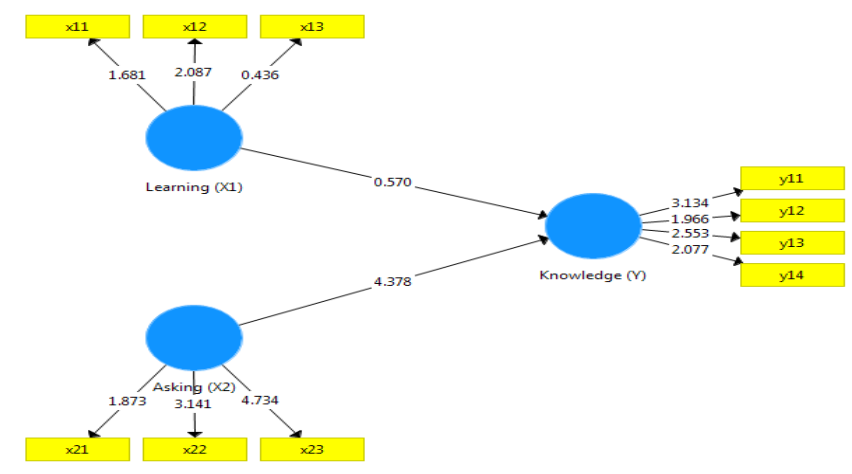

The effect test can be seen in the following table:

Table 1. The result of bootstrapping

\begin{tabular}{|l|c|c|c|c|c|}
\hline & $\begin{array}{c}\text { Original } \\
\text { Sample } \\
(\mathrm{O})\end{array}$ & $\begin{array}{c}\text { Sample } \\
\text { Mean } \\
(\mathrm{M})\end{array}$ & $\begin{array}{c}\text { Standard } \\
\text { Deviation } \\
(\mathrm{STDEV})\end{array}$ & T Statistics & P Values \\
\hline Asking $(\mathrm{X} 2)$-> Knowledge $(\mathrm{Y})$ & 0,449 & 0,468 & 0,103 & 4,378 & 0,000 \\
\hline Learning $(\mathrm{X} 1)$-> Knowledge $(\mathrm{Y})$ & $-0,127$ & $-0,097$ & 0,222 & 0,570 & 0,569 \\
\hline
\end{tabular}

The results show that the Asking variable is the dominant variable to know the application features. Learning variables have no significant effect to know application features.

Figure 2. Learning (X1)

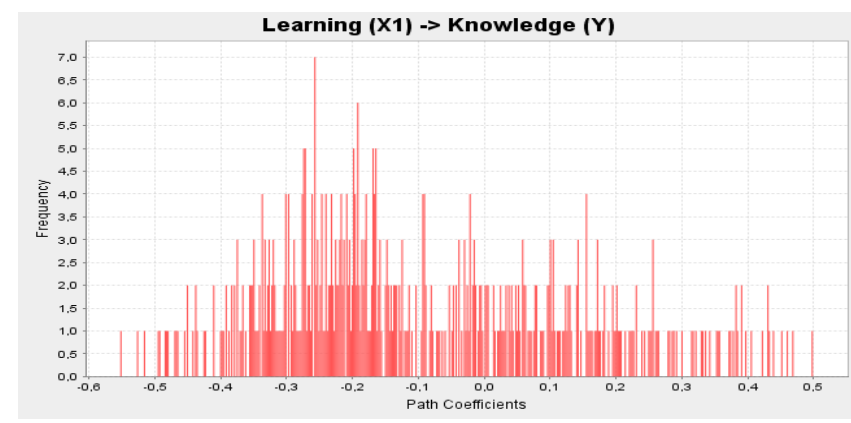

Source: PLS Output (2017)

Figure 3. Asking (X2)

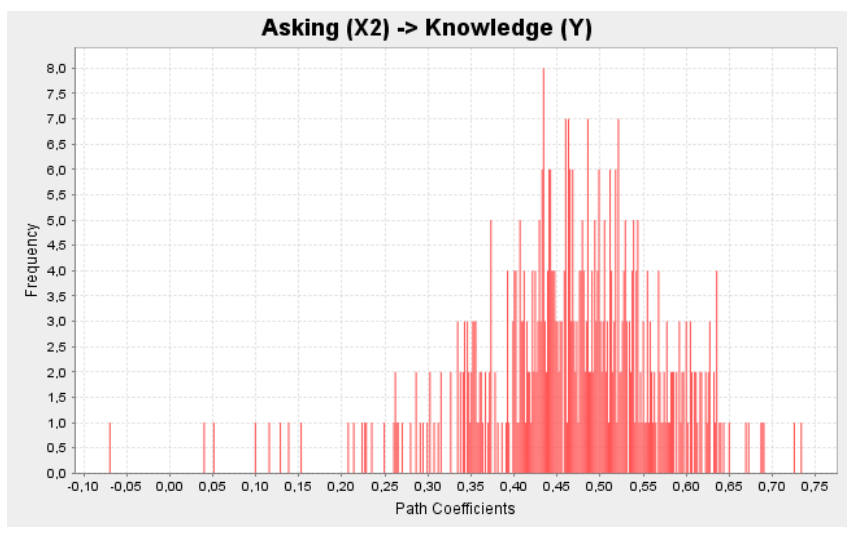

Source: PLS Output (2017)

Based on the above table the effect produces coefficient of 0.005 , smaller than $1.66(\alpha=5 \%)$ then the decision of hypothesis testing reject $\mathrm{HO}$ and accept the hypothesis $\mathrm{Ha}$ [4],[14],[15],[16]\&[17].In addition to hypothesis testing through the bootstrapping menu that produces T-statistics, inner model evaluation is also done by reviewing the R-Square value [21],[22],[23],[24],[25]\&[26]. The R-square value generated from the inner model evaluation is presented in the following table:

Table 2. R-Square Value

\begin{tabular}{|l|c|l|}
\hline & R Square & R Square Adjusted \\
\hline Knowledge (Y) & 0,225 & 0,211 \\
\hline
\end{tabular}


Figure 4. F-Square

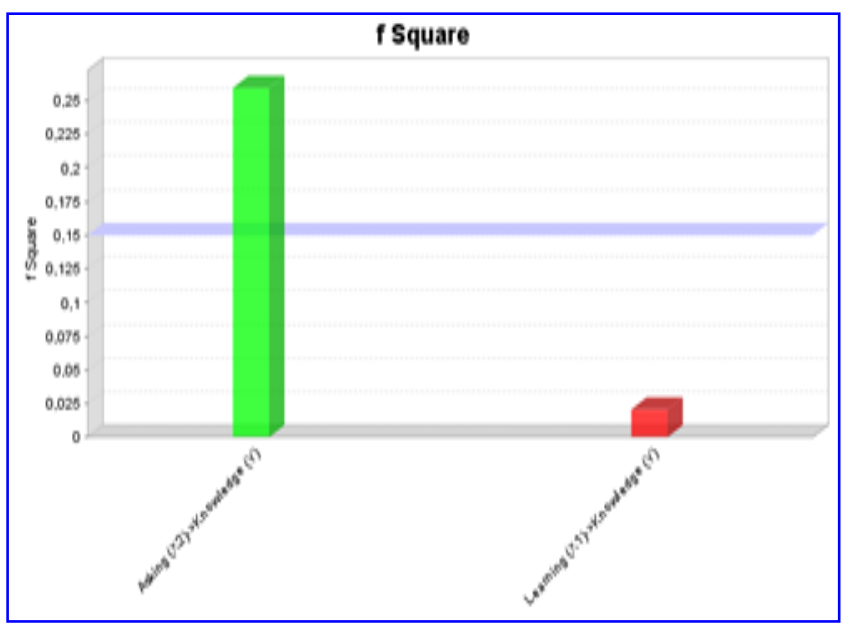

The development of transportation is also followed by technological developments. The development of information technology with a modern infrastructure has made various kinds of information can easily be obtained. More great, the services provided by information and communication technology today, can be accessed by anyone, regardless of distance and time. If technology was used only to communicate, current financial transactions and the provision of goods and services can already be done online[27],[28]\&[29]. Acceptance of technology use influenced by usefulness and ease of use.The perception of ease of use has a causal effect on perceived usefulness. Direct feature design affects perceived benefits and convenience perceptions use. Because the design features fall into the category of external variables within Fishbein paradigm, they do not theorize to have a direct effect on attitude or behavior, rather than affecting these variables only directly through perceived benefits and perceived ease of use[32],[34]\&[40] the intensity of use and interaction between users with the system can also showease of use. The more frequently used systems show that the system is easier to understand, easier to operate and easier touse.Based on these definitions, it can be concluded that the ease the use of computers depends on a person's level of confidence that the computer isit can be easily understood and the system used can be easily understood, operated and used.

The perception of the ease of using information technology is the dominant factor to explain the perception of the benefits and use of a system. Perceptions of benefits have a strong influence on system usage. The use of technology is related to the behavior of using the technology to accomplish the task. Utilization of information technology is a benefit expected by users of information systems in carrying out its duties, measurements based on the intensity of utilization, frequency of utilization, and the number of applications or software used[38]\&[39].The benefits of using Smartphone features can improve performance. Utilization is a benefit gained or expected by the users in carrying out their duties and work. Therefore, the level of usefulness during accessing the menu, will affect the interest in using the application system of transportation services.

\section{CONCLUSIONS}

The results show the level of community knowledge of smartphone features obtained through Asking more effectively to know the features of a smartphone than with a self-learning approach.

\section{REFERENCES}

[1] Ackaradejruangsri, P. "Insights on GrabTaxi: An Alternative Ride Service in Thailand'. Review of Integrative Business and Economics Research, Vol 4 Issue 3. (2015).49-58.

[2] Adissaranggoon, P. "The assessment of passengers awareness on the use of mobile application supporting CRM serving taxi service in Bangkok". In Cyber Technology in Automation, Control, and Intelligent Systems (CYBER), 2015 IEEE International Conference. (2015). (pp. $1012-$ 1016). IEEE.

[3] Amajida, F. D. "Digital Creativity in Urban Risk Communities: The Study of Online Ojek "Go-Jek" in Jakarta". Information, Vol. 46 Issue 1. (2014). pp.115-128.

[4] Azlina, Nur., Amir Hasan, Desmiyawati\&Muda, I. "The Effectiveness of Village Fund Management (Case Study at Villages in Coastal Areas in Riau)". International Journal of Economic Research. Vol.14 Issue 12. (2017). pp.325-336.

[5] Beldona, S., Morrison, A. M., \& O'Leary, J. "Online shopping motivations and pleasure travel products: a correspondence analysis”. Tourism Management, Vol. 26 Issue. 4. (2005). pp.561-570.

[6] Belk, R. "You are what you can access: Sharing and collaborative consumption online". Journal of Business Research, Vol.67 Issue 8. (2014). pp.1595-1600.

[7] Chu, R. "What online Hong Kong travelers look for on airline/travel websites?'. International Journal of Hospitality Management, Vol.20. Issue 1. (2001). pp.95-100.

[8] Dalimunthe., D.M.J.,Fadli, and Muda, I. "The application of performance measurement system model using Malcolm Baldrige Model (MBM) to support Civil State Apparatus Law (ASN) number 5 of 2014 in Indonesia". International Journal of Applied Business and Economic Research. Vol.14 Issue 11. (2016). pp.7397-7407.

[9] Erlina., Ari Saputra\&Muda, I. "Antecedents of Budget Quality Empirical Evidence from Provincial Government In Indonesia". International Journal of Economic Research. Vol. 14 Issue 12. (2017). pp.301-312.

[10] Erlina., Ari Saputra\&Muda, I. "The Analysis of the Influencing Factors of Budget Absorption". International Journal of Economic Research. Vol. 14 Issue 12. (2017). pp.287-300.

[11] Erlina.,"ConflictofInterestImpact: FactorsAnalysisAffectingtheBudgetQualityinMedanCity". International Journal of Economic Research. Vol.14 Issue 12. (2017). pp.135-145.

[12] Fink, A., \&Reiners, T. "Modeling and solving the short-term car rental logistics problem'. Transportation Research Part E: Logistics and Transportation Review, Vol.42 Issue 4. (2006). pp.272-292.

[13] Gunawan, S. "Consumer Perception For Grab Car Services In Surabaya”. Agora, Vol.5 Issue 3. (2017). pp.55-68.

[14] Gusnardi.,Riadi, R.M., and Muda, I. "Competency mapping and analysis of students competency based on economics subject national examination and its alternative solutions in state high schools at Pekanbaru". International Journal of Economic Research. Vol.3 Issue 5. (2016). pp.2133-2148.

[15] Hall, J. V., \& Krueger, A. B. An analysis of the labor market for Uber's driver-partners in the United States (No. w22843). (2016). National Bureau of Economic Research.

[16] Handoko, Bagus.,Sunaryo\&Muda, I. "Difference Analysis of Consumer Perception of Motorcycle Product Quality". International Journal of Economic Research. Vol. 14 Issue 12. (2017). pp.363-379.

[17] Hasan., Amir, Gusnardi\&Muda, I. "Analysis of Taxpayers and Understanding Awareness Increase in Compliance with Taxpayers 
Individual Taxpayers". International Journal of Economic Research. Vol.14 Issue 12. (2017). pp. 75-90.

[18] Kinney Jr, S. E., Rago, V. F., Meakem, G. T., Stevens, R. G., Becker, D. J., Bernard, A. F., ...\&Sobie, D. M. U.S. Patent No. 6,564,192. Washington, DC: U.S. (2003). Patent and Trademark Office.

[19] Lehto, X. Y., Kim, D. Y., \& Morrison, A. M. "The effect of prior destination experience on online information search behavior". Tourism and Hospitality Research, Vol.6 Issue 2. (2006). 160-178.

[20] Li, Z., \& Tao, F. "On determining optimal fleet size and vehicle transfer policy for a car rental company". Computers \& operations research, Vol.37 Issue 2. (2010). pp.341-350.

[21] Lubis., A.,Torong, Z.B., and Muda, I. "The urgency of implementing balanced scorecard system on local government in North Sumatra Indonesia". International Journal of Applied Business and Economic Research. Vol.14 Issue 11. (2016). pp.7575-7590.

[22] Lubis., A.F., Lubis, T.A., and Muda, I. "The role of Enterprise Resource Plan (ERP) configuration to the timeliness of the financial statement presentation". International Journal of Applied Business and Economic Research. Vol.14 Issue 11. (2016). pp.7591-7608.

[23] Lutfi., M.,Nazwar, C., and Muda, I "Effects of investment opportunity set, company size and real activity manipulation of issuers in Indonesia Stock Exchange on stock price in Indonesia". International Journal of Economic Research. Vol.13 Issue 5. (2016). pp.2149-2161.

[24] Muda., I and AbykusnoDharsuky. "Impact of Region Financial Information System (SIKD) Quality, Role Ambiguity And Training on Precision of Financial Statement of Local Government Presentation In North Sumatra". International Journal of Applied Business and Economic Research, Vol.13 Issue 6. (2015). pp.4283-4304.

[25] Muda., I, DeniYuwiliaWardani, Erlina, AzharMaksum, Ade FatmaLubis and Rina Bukit. "The Influence of Human Resources Competency and The Use of Information Technology on The Quality of Local Government Financial Report with Regional Accounting System as an Intervening". Journal of Theoretical and Applied Information Technology. Vol.95 Issue 17. (2017). pp.1432-1451.

[26] Muda., I, Dharsuky. A., Siregar, H.S., and Sadalia, I. "combined loading and Cross-dimensional loadings timeliness of presentation of financial statements of local government". IOP Conference Series: Materials Science and Engineering. Bandung, (2017). 180. doi: 10.1088/1757899X/180/1/012099.

[27] Muda., I, Marlon Sihombing, ErniJumilawati and AbikusnoDharsuky. "Critical Success Factors Downstream Palm Oil Based Small And Medium Enterprises (SME) In Indonesia". International Journal of Economic Research. Vol.13 Issue 8. (2016). pp. 3531-3538.

[28] Muda., I., Rafiki, A., \&Harahap, M. R. "Factors Influencing Employees' Performance: A Study on the Islamic Banks in Indonesia". International Journal of Business and Social Science, Vol.5Issue 2. (2014). pp. 73-80.

[29] Muda., I.,Dharsuky, A.,Sadalia, I., and Siregar, H.S. "Impact of capital investments and cash dividend policy on Regional Development Bank (BPD) PT. Bank Sumut to the district own source revenue and economic growth". International Journal of Applied Business and Economic Research. Vol.14 Issue 11. (2016). pp.7863-7880.

[30] Muda.,Iskandar. The Effect of Supervisory Board Cross-Membership and Supervisory Board Members' Expertise to The Disclosure of Supervisory Board's Report: Empirical Evidence From Indonesia. European Research Studies Journal. Vol.XX Issue 3A. (2017). pp.702716.

[31] Nasir, Azwir.,YesiMutiaBasri, Kamaliah\&Muda, I. "Effectiveness of Potential Tax Region as the Real Local Revenue Sources in Riau Coastal
Area". International Journal of Economic Research. Vol.14 Issue 12. (2017). pp.313-324.

[32] Natyari, S. G., \&Pradana, M. "Determinants Forming Uber Consumers' Preferences in Bandung City, Indonesia”. Safety, Vol 10Issue 6. pp.7-18.

[33] Paronda, A. G. A., Regidor, J. R. F., \&Gaabucayan-Napalang, M. S. "Comparative Analysis of Transportation Network Companies (TNCs) and Conventional Taxi Services in Metro Manila”. In Proc. of the 23rd Annual TSSP Conference.(2016).

[34] Prakoso, R. S. "Influence Mobile Service Quality Against Customer Satisfaction Case Study Say Taxi in Yogyakarta”. Doctoral dissertation, (2016). UII Yogyakarta.

[35] Rayle, L., Dai, D., Chan, N., Cervero, R., \&Shaheen, S. "Just a better taxi? A survey-based comparison of taxis, transit, and ridesourcing services in San Francisco". Transport Policy, Vol.45, (2016).pp.168178.

[36] Rayle, L., Shaheen, S., Chan, N., Dai, D., \&Cervero, R. App-based, ondemand ride services: Comparing taxi and ridesourcing trips and user characteristics in san Francisco university of California transportation center (UTC). (2014). UCTC-FR-2014-08.

[37] Sadalia, .Isfenti., Nur Ahmadi Bi Rahamani\&Muda, I. "The Significance of Internet-Based Financial Information Disclosure on Corporates' Shares in Indonesia". International Journal of Economic Research. Vol.14 Issue 12. (2017). pp.337-346.

[38] Sakunlertvattana, W. "Factors Influencing Consumer Brand Choice of Top 3 Taxi Booking Mobile Applications in Bangkok: Uber, GrabTaxi and Easy Taxi". (2016). Bangkok.

[39] Setiawan, J. "Consumer mapping based on factors causing using or not using UberX and Grab Taxi online transportation services in Bandung". (2017).

[40] Sukoco, Manik. "Grab and its development in Indonesia". Retrieve from https://www.kompasiana.com/maniksukoco/grab-danperkembangannya-di-indonesia_589496b19593732336948da0. 2017. Access on 12 July 2017.

[41] Tanus, V. V. "Analysis the impact of eTrust, perceived ease of use, perceived usefulness, attitude toward use, and intention to use Go-Jek mobile application in Surabaya". Doctoral dissertation. (2017). Widya Mandala Catholic University Surabaya).

[42] Taschler, E. "A crumbling monopoly: the rise of Uber and the Taxi Industry's struggle to survive". Chicago. (2015). Institute for Consumer Antitrust Studies.

[43] Tong, Y., Chen, Y., Zhou, Z., Chen, L., Wang, J., Yang, Q., ...\&Lv, W. "The Simpler The Better: A Unified Approach to Predicting Original Taxi Demands based on Large-Scale Online Platforms". In Proceedings of the 23rd ACM SIGKDD International Conference on Knowledge Discovery and Data Mining. (2017).pp. 1653-1662. ACM.

[44] Wahyuningtyas, S. Y. "The Online Transportation Network in Indonesia: A Pendulum between the Sharing Economy and Ex Ante Regulation". Competition and Regulation in Network Industries, Vol.17. Issue (3-4). (2016). pp.260-280.

[45] Wallsten, S. "The competitive effects of the sharing economy: how is Uber changing taxis?”. (2015).Technology Policy Institute, 22.

[46] Widjaja, A. T. "The influence of word of mouth and electronic word of mouth on purchase intention: a case study on consumer behavior on online ojek service". Journal of Business and Management, Vol.53 Issue.12. (2016). pp. 60-71.

[47] Yahya.,Idhar., Torong, Z.B., and Muda, I.. "Influence Behavior in Legislature Budget Development of Regions in the Province of Aceh and North Sumatra". International Journal of Economic Research, Vol.14 Issue 8. (2017). pp. 147-159. 